\title{
KAJIAN EFISIENSI SISTEM WAFFLE SLAB TERHADAP PELAT KONVENSIONAL
}

\author{
Paula $^{1}$ dan Edison Leo ${ }^{2}$ \\ ${ }^{1}$ Program Studi Sarjana Teknik Sipil, Universitas Tarumanagara, Jl. Letjen S. Parman No.1 Jakarta \\ Email: paula.setiawan@yahoo.com \\ ${ }^{2}$ Program Studi Sarjana Teknik Sipil, Universitas Tarumanagara, Jl. Letjen S. Parman No.1 Jakarta \\ Email: edisonl@ft.untar.ac.id
}

\begin{abstract}
ABSTRAK
Pelat dengan pelat tipis dan kumpulan balok rusuk berbentuk T yang saling menyilang dikenal dengan nama Waffle Slab. Di antara berbagai sistem pelat, sistem waffle slab masih jarang sekali digunakan, padahal sistem waffle slab memiliki keuntungan yaitu dengan ketebalan pelat yang sangat tipis dan pemakaian besi tulangan yang cukup hemat pada pelatnya dikarenakan pelat waffle slab memiliki kekakuan yang besar pada pelat sehingga lendutan pada pelat relatif kecil. Selain itu, penggunaan sistem waffle slab juga dapat mempengaruhi tata letak kolom. Semakin kecilnya lendutan pada balok maka jarak antar kolom pada portal bisa lebih jauh dari struktur yang biasa. Tujuan dari studi ini adalah untuk membandingkan sistem waffle slab dengan sistem pelat konvensional ditinjau dari segi kekakuan, ketebalan pelat, jarak antar kolom dan penggunaan material beton serta tulangan. Metode untuk analisis struktur menggunakan equivalent frame method dan menggunakan finite element program. Dari hasil analisis dapat disimpulkan bahwa pada sistem waffle slab, jarak antar kolom dapat lebih panjang dibandingkan dengan sistem pelat konvensional dan dengan tebal pelat yang lebih tipis, sistem waffle slab lebih kaku dibandingkan dengan sistem pelat kovensional. Hasil analisis tulangan menunjukan perbandingan penggunaan volume beton dan tulangan baja pada sistem waffle slab bisa lebih sedikit jumlahnya dibandingkan dengan sistem pelat konvensional.
\end{abstract}

Kata kunci: waffle slab, pelat konvensional, kekakuan.

\section{PENDAHULUAN}

Suatu bangunan gedung bertingkat memiliki beberapa komponen struktur atas salah satunya adalah pelat. Pelat merupakan elemen struktur yang menerima gravity loads pada gedung baik berupa beban mati maupun beban hidup secara langsung yang sifatnya lebih dominan terhadap lentur dengan bentuk yang melebar dan ketebalan yang relatif kecil (Costa \& Araujo, 2014; Susanti, Youlanda, \& Winaya, 2016). Beban gravitasi yang bekerja pada pelat akan disalurkan ke kolom melalui hubungan dari balok-balok (Pillai \& Menon, 2003).

Berdasarkan buku yang ditulis Pillai \& Menon (2003), sistem pelat terdiri dari beberapa macam yaitu (1) sistem flat plate adalah sistem pelat yang ditopang secara langsung oleh kolom tanpa adanya balok, (2) sistem flat slab adalah pelat yang diperkaku di bagian dengan kolom yang disokong oleh drop panel, (3) sistem ribbed slab adalah sistem pelat yang terdiri dari pelat yang tipis dan balok-balok rusuk. Balok rusuk dapat di desain sebagai one-way ribbed slab, (4) atau bisa juga di desain sebagai two-way ribbed slab atau yang dikenal sebagai sistem waffle slab, (5) dan sistem pelat konvensional adalah sistem pelat yang ditopang oleh balok yang kaku.

Waffle slab dapat divisualisasikan sebagai kumpulan dari balok $\mathrm{T}$ yang saling menyilang dan saling berhubungan pada bidang horizontal yang membentuk ruang-ruang kecil dimana balok silang tersebut menumpu pelat tipis di atasnya (Park \& Gamble, 1980). Pada umumnya sistem waffle slab ini menggunakan bahan dari konstruksi beton bertulang dengan ketebalan pelat yang sangat tipis dan pemakaian besi tulangan yang cukup hemat pada pelatnya dikarenakan pelat waffle slab memiliki kekakuan yang besar pada pelat sehingga lendutan pada pelat relatif kecil (Susanti, Youlanda, \& Winaya, 2016). Selain itu, penggunaan sistem waffle slab juga dapat mempengaruhi tata letak kolom. Semakin kecilnya lendutan pada balok maka jarak antar kolom pada portal bisa lebih jauh dari struktur yang biasa, umumnya panjang bentang bisa mencapai sekitar 10 m (Park \& Gamble, 1980).

Di antara berbagai sistem pelat, sistem waffle slab masih jarang sekali digunakan. Waffle slab biasanya digunakan pada proyek-proyek khusus yang membutuhkan ruangan yang luas dengan jumlah kolom yang sedikit dan ruangan dengan pelat lantai yang memiliki lendutan yang kecil dan frekuensi getaran yang kecil. Biasanya digunakan dalam pembangunan bandara, jembatan, gedung parkir, serta bangunan komersil dan industri, perpustakaan atau gallery art yang mengutamakan nilai estetika pada plafon bangunan. 
Pada studi penelitian ini penulis akan melakukan analisis dan desain kajian efisiensi dalam penggunaan sistem waffle slab terhadap pelat konvensional ditinjau dari segi kekakuan, ketebalan pelat, jarak antar kolom dan penggunaan material beton serta tulangan.

\section{Beton dan beton bertulang}

Beton adalah suatu massa padat yang terbuat dari gabungan material yang terdiri dari pasir, kerikil semen, dan air. Beton sangat kuat terhadap tekan, tetapi sangat lemah terhadap tarik. Kekuatan tariknya hanya 1/10 dari kuat tekannya (Pillai \& Menon, 2003). Sebagai hasilnya, retakan akan timbul ketika beban, penyusutan, atau perubahan suhu menibulkan tegangan tarik yang melebihi kekuatan tarik beton. Untuk itu, diperlukan tulangan baja di dalam beton untuk menahan gaya tarik tersebut (Wight, 2016).

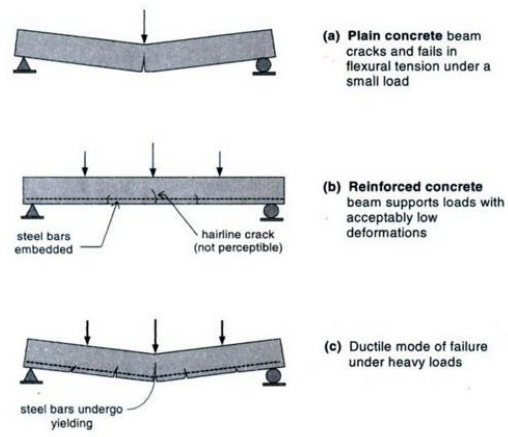

Gambar 1. Kontribusi tulangan baja dalam beton bertulang (Reinforced Concrete Design, 2003:6)

\section{Pelat}

Pelat adalah komponen horizontal struktur yang menahan beban gravitasi (beban mati dan beban hidup) yang bekerja dan menyalurkannya ke rangka vertikal dari sistem struktur. Pelat bekerja sebagai diafragma/unsur pengaku horizontal yang bermanfaat untuk mendukung kekakuan dari elemen rangka vertikal struktur (Pillai \& Menon, 2003).

\section{Sistem pelat}

Dalam buku yang ditulis oleh Pillai \& Menon (2003), dalam konstruksi beton bertulang, pelat biasanya terdiri dari salah satu sistem di bawah ini:

1. Sistem Pelat Ditumpu oleh Dinding (Wall-Supported Slab System)

Pada sistem ini, tebal pelat berkisar antara 100-200 mm dengan panjang bentang sekitar 3-7,5 m ditumpu oleh load-bearing walls. Sistem ini digunakan terutama pada bangunan tingkat rendah.

2. Sistem Pelat Ditumpu oleh Balok (Beam-Supported Slab System)

Sistem ini umumnya digunakan pada bangunan tingkat tinggi dan juga struktur rangka tingkat rendah. Beban gravitasi yang bekerja pada pelat diteruskan ke kolom melalui hubungan balok. Balok yang langsung berhubungan dengan kolom disebut balok induk (atau girders), sedangkan balok yang ditumpu oleh balok induk dinamakan balok anak.

Berdasarkan kemampuannya untuk menyalurkan gaya akibat beban, pelat dibedakan menjadi pelat satu arah dan pelat dua arah. Hal ini ditentukan berdasarkan momen lentur yang lebih dominan pada bentang satu arah atau dua arah dengan membandingkan berdasarkan rasio bentang terpanjang dan bentang terpendeknya (Pillai \& Menon, 2003).

\section{Waffle slab}

Untuk bentang pelat yang panjang dan relatif memikul beban hidup yang ringan dapat di desain dengan konstruksi balok jois menjadi sistem waffle slab (Wight, 2016). Menurut SNI 2847:2013, konstruksi balok jois terdiri dari kombinasi monolit rusuk berspasi beraturan dan slab diatasnya yang disusun untuk membentang dalam satu arah atau dua arah ortogonal. Ketentuan dalam menentukan jarak antar rusuk dan dimensi rusuk adalah sebagai berikut:

1. Lebar rusuk tidak boleh kurang dari $100 \mathrm{~mm}$,

2. Tinggi rusuk tidak lebih dari 31/2 kali lebar minimum badannya,

3. Spasi bersih antar rusuk tidak boleh melebihi $750 \mathrm{~mm}$.

Konstruksi balok jois yang tidak memenuhi batasan di atas harus dirancang sebagai slab dan balok. 


\section{Lendutan}

Agar dapat menahan deformasi akibat lendutan tanpa menimbulkan kerusakan maka pada suatu struktur beton harus disyaratkan mempunyai kekuatan yang cukup kuat. Nilai lendutan yang terjadi tidak boleh melebihi nilai lendutan ijin yang disyaratkan dalam SNI 2847-2013 pasal 9.5.3.1 sebagai berikut:

1. L/240 untuk konstruksi atap atau lantai yang menumpu atau disatukan dengan komponen nonstruktural yang mungkin tidak akan rusak oleh lendutan yang besar.

2. L/360 untuk lantai yang tidak menumpu atau tidak disatukan dengan komponen nonstruktural yang mungkin akan rusak oleh lendutan yang besar.

\section{Tebal minimum pelat}

Berikut beberapa syarat ketentuan yang harus diperhatikan dalam menetukan tebal pelat untuk pelat konvensional.

\section{Konstruksi Pelat 1 Arah}

Menurut SNI 2847:2013 pasal 9.5.2.1, tebal minimum yang ditentukan dalam Tabel 9.5(a) berlaku untuk konstruksi satu arah yang tidak menumpu atau tidak disatukan dengan partisi atau konstruksi lain yang mungkin akan rusak akibat lendutan yang besar, kecuali bila perhitungan lendutan menunjukkan bahwa ketebalan yang lebih kecil dapat digunakan tanpa menimbulkan pengaruh yang merugikan.

\section{Konstruksi Pelat 2 Arah}

Menurut SNI 2847:2013 pasal 9.5.3.2, untuk pelat tanpa balok interior yang membentang di antara tumpuan dan mempunyai rasio bentang panjang terhadap bentang pendek yang tidak lebih dari 2, tebal minimumnya harus memenuhi ketentuan Tabel 9.5(c) pada SNI 2847:2013 dan tidak boleh kurang dari nilai berikut:

a) Tanpa panel drop (drop panels) yaitu $125 \mathrm{~mm}$

b) Dengan panel drop (drop panels) yaitu $100 \mathrm{~mm}$

Menurut SNI 2847:2013 pasal 9.5.3.3, Untuk pelat dengan balok yang membentang di antara tumpuan pada semua sisinya, tebal minimumnya, h, harus memenuhi ketentuan sebagai berikut:

a) Jika $\alpha \mathrm{m}<0,2$ maka $\mathrm{h} \geq 120 \mathrm{~mm}$

b) Jika $0,2 \leq \alpha \mathrm{m} \leq 2$ maka:

$$
h=\frac{L n\left(0,8+\frac{f y}{1400}\right)}{36+5 \beta(\alpha m-0,2)} \text { dan } \mathrm{h} \geq 120 \mathrm{~mm}
$$

c) Jika $\alpha \mathrm{m}>2$ maka:

$$
h=\frac{L n\left(0,8+\frac{f y}{1400}\right)}{36+9 \beta} \text { dan } \mathrm{h} \geq 90 \mathrm{~mm}
$$

dengan $\beta=$ rasio bentang bersih pelat dalam arah memanjang dan arah memendek, Ln = panjang bersih pada arah memanjang dari konstruksi dua arah,yang diukur dari muka ke muka tumpuan pada pelat tanpa balok, $\alpha \mathrm{m}=$ nilai $\alpha$ rata-rata, dan $\alpha=$ rasio kekakuan lentur penampang balok terhadap kekakuan lentur pelat

$\alpha=\frac{\text { Ec x Ib }}{\operatorname{Ecs} \times \text { Is }}$

dengan $\mathrm{Ec}=$ modulus elastisitas beton, $\mathrm{Ecs}=$ modulus elastisitas pelat beton, $\mathrm{Ib}=$ momen inersia terhadap sumbu titik pusat penampang bruto balok, dan Is = momen inersia terhadap sumbu titik pusat penampang bruto pelat.

\section{Konstruksi Waffle Slab}

Menurut SNI 03-2847-2013 pasal 8.13.6.1 tebal pelat pada sistem waffle slab harus memenuhi syarat berikut:

a) $h \geq 50 \mathrm{~mm}$

b) $h \geq \operatorname{Ln} / 12$

\section{Equivalent frame method}

Pada portal ekuivalen, kolom dianggap menyatu dengan balok-pelat transversal terhadap bentangan yang ditinjau melalui aksi torsi (Wight, 2016). Balok pelat yang mengalami torsi ini membentang dari garis sumbu-sumbu panel yang membatasi masing-masing sisi dari balok pelat yang ditinjau. Aksi torsi dari balok-pelat transversal akan 
mengurangi kekakuan lentur efektif dari kolom aktual. Efek ini diperhitungkan dalam analisis dalam bentuk Kolom Ekuivalen yang mempunyai kekakuan lentur lebih kecil dari kolom aktualnya.

Besarnya nilai kekakuan lentur kolom ekuivalen dapat ditentukan sebagai berikut:

$\frac{1}{K e c}=\frac{1}{\sum K c}+\frac{1}{K t}$

dengan Kec = kekakuan lentur kolom ekuivalen, $\Sigma \mathrm{Kc}=$ jumlah kekakuan lentur kolom actual dari kolom atas dan bawah pelat, dan $\mathrm{Kt}=$ kekakuan punter dari penahan puntir (torsion arm).

Nilai kekakuan torsi Kt dapat ditentukan sebagai berikut:

$K t=\sum \frac{9 E c s C}{l 2\left(1-\frac{c 2}{l 2}\right)^{3}}$

dengan Ecs $=$ modulus elastisitas balok pelat, $\mathrm{c}_{2}=$ ukuran kolom, $\mathrm{l}_{2}=$ lebar dari balok pelat yang ditinjau, dan $\mathrm{C}=$ konstanta penampang untuk menentukan kekakuan punter yang dapat dihitung dengan rumus

$$
C=\sum\left[\left(1-0.63 \frac{X}{Y}\right) \frac{X^{3} Y}{3}\right]
$$

Kekakuan kolom ekuivalen (Kec), kekakuan balok pelat (Kcs) kemudian digunakan untuk memnentukan faktor distribusi (Analisa Struktur dengan Metode Cross) dari setiap elemen struktur untuk mendapatkan momen- momen terfaktor (momen negatif, momen positif, dan momen ujung kolom) pada masing-masing ujung batang. Distribusi momen terfaktor yang diperoleh dari hasil analisis struktur kemudian didistribusikan ke masing-masing lajur kolom (column strip) dan lajur tengah (middle strip).

\section{Penulangan lentur}

Desain penulangan dilakukan sesuai dengan SNI 2847:2013, dengan desain tulangan ditentukan oleh rasio tulangan. Rasio tulangan harus berada diantara rasio tulangan minimum dan maksimum untuk menjamin struktur dalam keadaan daktail.

Rasio tulangan minimum, $\rho \min =\frac{1,4}{f y}$

Rasio tulangan maksimum $(\rho \max )=0,75 \rho \mathrm{b}$

$\rho b=\frac{0.85 \mathrm{f} / \mathrm{c}}{f y} \beta 1\left(\frac{600}{600+f y}\right)$

dengan fy = mutu baja tulangan $(\mathrm{MPa}), \mathrm{fc}^{\prime}=$ mutu beton $(\mathrm{MPa})$

Jumlah luas tulangan yang diperlukan tergantung dari nilai rasio tulangan.

$A s=\rho b d$

dengan As = luas Tulangan yang diperlukan $\left(\mathrm{mm}^{2}\right), \rho=$ rasio tulangan, dan $\mathrm{b}$ dan $\mathrm{d}=$ dimensi elemen struktur beton.

Dimensi elemen struktur dan jumlah tulangan yang digunakan memiliki kekuatan menahan beban yang disebut dengan kapasitas. Kapasitas lentur beton bertulang adalah sebagai berikut:

$M n=C c(d-a / 2)=0,85 f c^{\prime} \cdot a \cdot b(d-\mathrm{a} / 2)$

atau

$M n=T(d-a / 2)=A s . f y(d-\mathrm{a} / 2)$

Nilai kapasitas dari elemen struktur ini harus melebihi nilai momen lentur yang terjadi akibat adanya beban-beban. Analisa struktur akan menganalisis gaya dalam yang terjadi pada elemen struktur tersebut akibat beban ultimate. Hasil analisis struktur untuk momen lentur adalah Momen Ultimate $(\mathrm{Mu})$. Nilai Mu ini yang harus memenuhi persamaan, $M u \leq \emptyset M n$ agar persyaratan keamanan struktur dapat dipenuhi.

\section{Analisis kuat geser pelat}

Ada dua jenis geser yang harus ditinjau:

1. Geser satu arah atau geser balok meninjau penampang kritis pada jarak d dari muka kolom dan pelat ditinjau sebagai balok lebar yang membentang antar tumpuannya. 
2. Geser dua arah atau geser ponds yang terjadi sekeliling kerucut terpancung. Penampang kritis terletak pada $\mathrm{d} / 2$ dari muka kolom, capital, atau drop panel.

Untuk kondisi tanpa tulangan geser, kuat geser beton diambil sebagai nilai terkecil dari:

$\phi V c=\phi \frac{1}{3} \sqrt{f^{\prime} c} \cdot$ bo.d

$\phi V c=\phi\left(1+\frac{2}{\beta c}\right) \frac{1}{6} \sqrt{f^{\prime} c}$. bo.d

dengan $\beta \mathrm{c}=$ rasio sisi panjang kolom terhadap sisi pendeknya

$\phi V c=\phi\left(\frac{\alpha s \cdot d}{b o}+2\right) \frac{1}{12} \sqrt{f^{\prime} c} \cdot$ bo.d

dengan $\alpha$ s $=40$ untuk kolom interior, 30 untuk kolom tepi, dan 20 untuk kolom susut.

\section{METODOLOGI PENELITIAN}

Penelitian ini dilakukan berdasarkan hasil analisis dengan bantuan program. Dalam melaksanakan penelitian dan analisis, langkah-langkah yang ditempuh penulis digambarkan melalui diagram alir penelitian seperti pada Gambar 2.

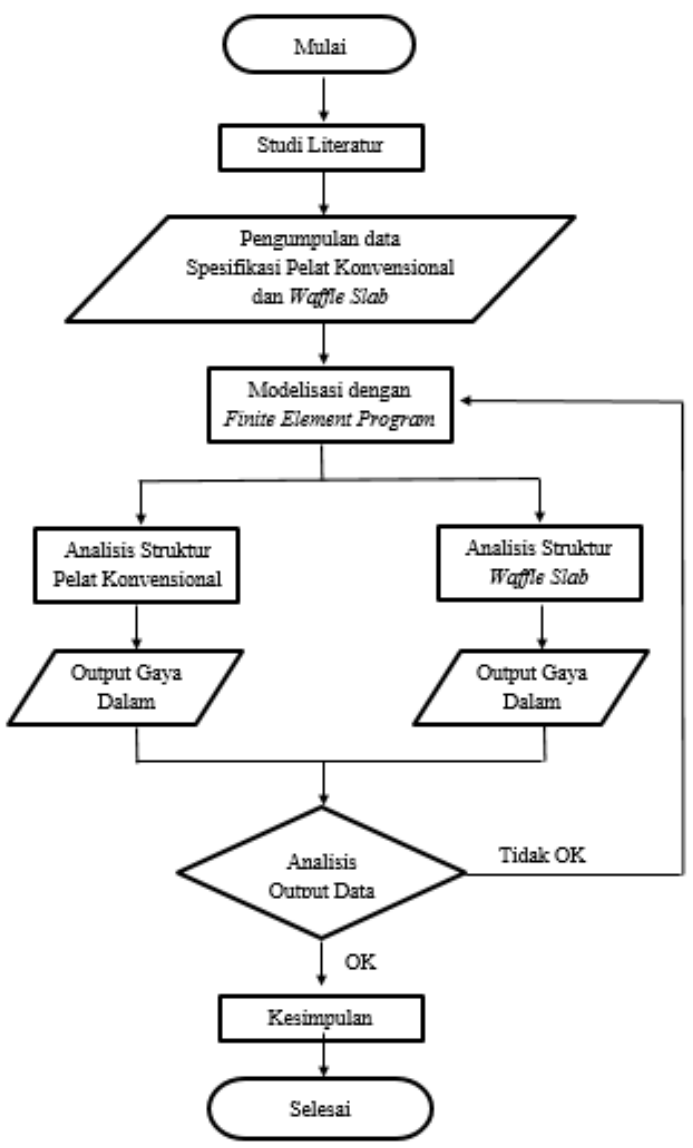

Gambar 2. Diagram alir penelitian

\section{ANALISIS DAN PEMBAHASAN}

\section{Data spesifikasi}

Tinggi story

Superimposed Dead Load, SDL

Live Load (fungsi bangunan perpustakaan) $=479 \mathrm{~kg} / \mathrm{m}^{2}$

Ukuran Kolom

$=500 / 500 \mathrm{~mm}$

$$
\begin{array}{lll}
=4 \mathrm{~m} & \mathrm{f}^{\prime} \mathrm{c} \text { balok dan pelat } & =35 \mathrm{MPa} \\
=225 \mathrm{~kg} / \mathrm{m}^{2} & \mathrm{f}^{\prime} \mathrm{c} \text { kolom } & =40 \mathrm{MPa} \\
=479 \mathrm{~kg} / \mathrm{m}^{2} & \text { fy } & =400 \mathrm{MPa}
\end{array}
$$


Ukuran Balok Induk $\quad=400 / 800 \mathrm{~mm}$

Ukuran Balok Rusuk sesuai dengan yang diatur dalam SNI 2847-2013 Pasal 8.13 mengenai Konstruksi Balok Jois sebagai berikut:

1) Lebar rusuk tidak boleh kurang dari $100 \mathrm{~mm}$. SNI 2847:2013 (8.13.2)

Gunakan lebar rusuk $100 \mathrm{~mm}$.

2) Tinggi rusuk tidak lebih dari 31/2 kali lebar minimum badannya. SNI 2847:2013 (8.13.2)

$3,5 \times 100 \mathrm{~mm}=350 \mathrm{~mm} \rightarrow$ Gunakan tinggi rusuk $350 \mathrm{~mm}$.

3) Spasi bersih antar rusuk tidak boleh melebihi $750 \mathrm{~mm}$. SNI 2847:2013 (8.13.3)

Spasi antar rusuk $820 \mathrm{~mm}$.

4) Tebal slab tidak boleh kurang dari: SNI 2847:2013 (8.13.6.1)

a) $1 / 12$ jarak bersih antar rusuk $=1 / 12 \times 750=62,5 \mathrm{~mm}$.

b) $50 \mathrm{~mm}$.

Digunakan tebal slab $80 \mathrm{~mm}>62,5 \mathrm{~mm}$.

\section{Analisis bentang maksimum pelat}

Dengan menetapkan tebal pelat $125 \mathrm{~mm}$, dan ukuran balok seperti pada data spesifikasi di atas, dilakukan analisis bentang maksimum pelat terhadap sistem waffle slab dan sistem pelat konvensional dengan kombinasi pembebanan $1 \mathrm{DL}+1 \mathrm{SDL}+1 \mathrm{LL}$ seperti yang ditunjukan pada Tabel 1 dan Tabel 2.

Tabel 1. Hasil analisis bentang maksimum sistem pelat konvensional

\begin{tabular}{cccccccc}
\hline No & Jarak antar & \multicolumn{2}{c}{ Lendutan Max (mm) } & $\begin{array}{c}\text { Lendutan } \\
\text { Ijin }(\mathbf{m m})\end{array}$ & Lendutan Max (mm) & $\begin{array}{c}\text { Lendutan } \\
\text { Ijin (mm) }\end{array}$ \\
\cline { 2 - 8 } & Kolom (m) & $\begin{array}{c}\text { Dead Load + } \\
\text { Live Load } \\
\text { Tipe 1 }\end{array}$ & $\begin{array}{c}\text { Dead Load + } \\
\text { Live Load } \\
\text { Tipe 2 }\end{array}$ & L/240 & $\begin{array}{c}\text { Live Load } \\
\text { Tipe 1 }\end{array}$ & $\begin{array}{c}\text { Live Load } \\
\text { Tipe 2 }\end{array}$ & L/360 \\
\hline 1 & 15 & 101.9710 & 112.2720 & 62.5000 & 47.1530 & 56.6660 & 41.6667 \\
\hline 2 & 10 & 47.2870 & 51.9000 & 41.6667 & 22.2320 & 26.6270 & 27.7778 \\
\hline 3 & 9.5 & 38.7280 & 42.5880 & 39.5833 & 18.1440 & 21.9730 & 26.3889 \\
\hline 4 & 9.2 & 33.8840 & 37.2270 & 38.3333 & 15.8404 & 19.1810 & 25.5556 \\
\hline 5 & 9 & 31.7860 & 34.8800 & 37.5000 & 14.8480 & 17.9420 & 25.0000 \\
\hline 6 & 7 & 12.6620 & 13.7460 & 29.1667 & 5.8310 & 6.9120 & 19.4444 \\
\hline 7 & 5 & 3.5550 & 3.6820 & 20.8333 & 1.6610 & 1.8480 & 13.8889 \\
\hline
\end{tabular}

Tabel 2. Hasil analisis bentang maksimum sistem waffle slab

\begin{tabular}{|c|c|c|c|c|c|c|c|}
\hline \multirow[b]{2}{*}{ No } & \multirow[b]{2}{*}{$\begin{array}{l}\text { Jarak antar } \\
\text { Kolom (m) }\end{array}$} & \multicolumn{2}{|c|}{ Lendutan Max (mm) } & \multirow{2}{*}{$\begin{array}{c}\text { Lendutan } \\
\text { Ijin (mm) } \\
\text { L/240 }\end{array}$} & \multicolumn{2}{|c|}{ Lendutan Max (mm) } & \multirow{2}{*}{$\begin{array}{c}\text { Lendutan } \\
\text { Ijin (mm) } \\
\text { L/360 }\end{array}$} \\
\hline & & $\begin{array}{c}\text { Dead Load + } \\
\text { Live Load } \\
\text { Tipe } 1\end{array}$ & $\begin{array}{l}\text { Dead Load + } \\
\text { Live Load } \\
\text { Tipe } 2\end{array}$ & & $\begin{array}{c}\text { Live } \\
\text { Load } \\
\text { Tipe } 1\end{array}$ & $\begin{array}{c}\text { Live } \\
\text { Load } \\
\text { Tipe } 2\end{array}$ & \\
\hline 1 & 15 & 104.9930 & 108.8780 & 62.5000 & 46.3940 & 50.9650 & 41.6667 \\
\hline 2 & 13 & 57.8590 & 59.6970 & 54.1667 & 25.6010 & 27.7310 & 36.1111 \\
\hline 3 & 12.5 & 49.1730 & 50.7499 & 52.0833 & 21.7730 & 23.6320 & 34.7222 \\
\hline 4 & 12 & 41.3019 & 42.7313 & 50.0000 & 18.2510 & 19.8540 & 33.3333 \\
\hline 5 & 10 & 18.8680 & 19.5860 & 41.6667 & 8.3500 & 9.0180 & 27.7778 \\
\hline 6 & 9.2 & 14.1746 & 14.4675 & 38.3333 & 6.3503 & 6.8220 & 25.5556 \\
\hline 7 & 5 & 1.0570 & 1.0880 & 20.8333 & 0.4652 & 0.4830 & 13.8889 \\
\hline
\end{tabular}

Jarak antar kolom maksimum pada sistem pelat konvensional adalah 9,2 m, sedangkan pada sistem waffle slab adalah 12,5 m, maka jarak antar kolom pada sistem waffle slab lebih panjang $35 \%$ dibandingkan dengan sistem pelat konvensional. 


\section{Analisis lendutan}

Dengan bentang jarak antar kolom yang sama, lendutan pada sistem pelat konvensional lebih besar dibandingkan dengan sistem waffle slab. Bila di rata-rata, terdapat perbedaan nilai lendutan sekitar 130\% yang dapat dilihat pada Tabel 3.

Tabel 3. Perbedaan nilai lendutan

\begin{tabular}{cccc}
\hline $\begin{array}{c}\text { Jarak antar } \\
\text { Kolom }(\mathbf{m})\end{array}$ & $\begin{array}{c}\text { Lendutan Max } \\
\text { Waffle Slab }\end{array}$ & $\begin{array}{c}\text { Lendutan Max } \\
\text { Pelat Konvensional }\end{array}$ & $\begin{array}{c}\text { Perbandingan } \\
(\mathbf{\%})\end{array}$ \\
\hline 5 & 1.057 & 3.555 & 236.3292 \\
\hline 9.2 & 14.1746 & 33.884 & 139.0473 \\
\hline 10 & 18.868 & 47.287 & 150.6201 \\
\hline 15 & 104.993 & 101.971 & 2.8783 \\
\hline \multicolumn{5}{r}{ Rata-rata } & 132.2187 \\
\hline
\end{tabular}

\section{Analisis tebal minimum pelat}

Berdasarkan bentang maksimum pelat, dilakukan analisis tebal minimum pelat. Untuk sistem waffle slab digunakan bentang $12,5 \mathrm{~m}$ dan jarak antar balok rusuk $0,92 \mathrm{~m}$. Sedangkan untuk sistem pelat konvensional digunakan bentang 9,2 m. Hasil analisis tebal minimum pelat ditabelkan seperti yang ditunjukan pada Tabel 4 .

Tabel 4. Hasil analisis tebal minimum pelat

\begin{tabular}{|c|c|c|c|c|c|c|c|}
\hline \multicolumn{4}{|c|}{ Sistem Pelat Konvensional } & \multicolumn{4}{|c|}{ Sistem Waffle Slab } \\
\hline \multirow[t]{2}{*}{ No } & \multirow{2}{*}{$\begin{array}{c}\text { Tebal } \\
\text { Minimum } \\
\text { Pelat }(\mathbf{m m})\end{array}$} & \multirow{2}{*}{$\begin{array}{c}\text { Lendutan } \\
\text { Max } \\
(\mathbf{m m})\end{array}$} & $\begin{array}{l}\text { Lendutan } \\
\text { Ijin }(\mathrm{mm})\end{array}$ & \multirow[t]{2}{*}{ No } & \multirow{2}{*}{$\begin{array}{c}\text { Tebal } \\
\text { Minimum } \\
\text { Pelat }(\mathrm{mm})\end{array}$} & \multirow{2}{*}{$\begin{array}{c}\text { Lendutan } \\
\text { Max } \\
\text { (mm) }\end{array}$} & $\begin{array}{l}\text { Lendutan } \\
\text { Ijin }(\mathrm{mm})\end{array}$ \\
\hline & & & $\mathrm{L} / 240$ & & & & $\mathrm{~L} / 240$ \\
\hline 1 & 100 & 53.378 & 38.3333 & 1 & 62.5 & 57.208 & 52.0833 \\
\hline 2 & 125 & 37.227 & 38.3333 & 2 & 80 & 52.415 & 52.0833 \\
\hline 3 & 130 & 34.477 & 38.3333 & 3 & 100 & 49.786 & 52.0833 \\
\hline 4 & 140 & 27.287 & 38.3333 & & & & \\
\hline 5 & 150 & 24.044 & 38.3333 & & & & \\
\hline 5 & 180 & 17.599 & 38.3333 & & & & \\
\hline 6 & 200 & 14.932 & 38.3333 & & & & \\
\hline
\end{tabular}

Untuk jarak antar kolom yang sama yaitu 9,2 m, tebal pelat pada sistem pelat konvensional adalah $125 \mathrm{~mm}$ dan tebal pelat pada sistem waffle slab adalah $80 \mathrm{~mm}$, maka sistem waffle slab memiliki tebal pelat lebih tipis 56,25\% dari sistem pelat konvensional.

\section{Analisis momen pada pelat}

Analisis struktur pada pelat menggunakan bantuan dari finite element program dan dicocokan dengan perhitungan manual dengan metode portal ekuivalen (equivalent frame method). Hasil analisis struktur berupa momen untuk sistem pelat konvensional dapat dilihat pada Gambar 3 dan untuk sistem waffle slab dapat dilihta pada Gambar 4. 


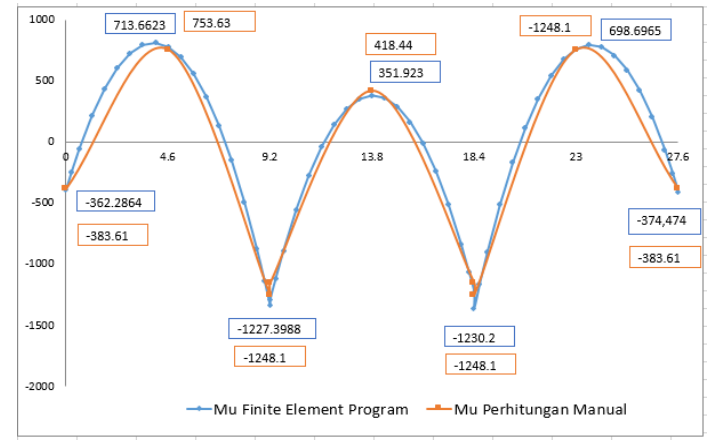

Gambar 3. Diagram momen sistem pelat konvensional

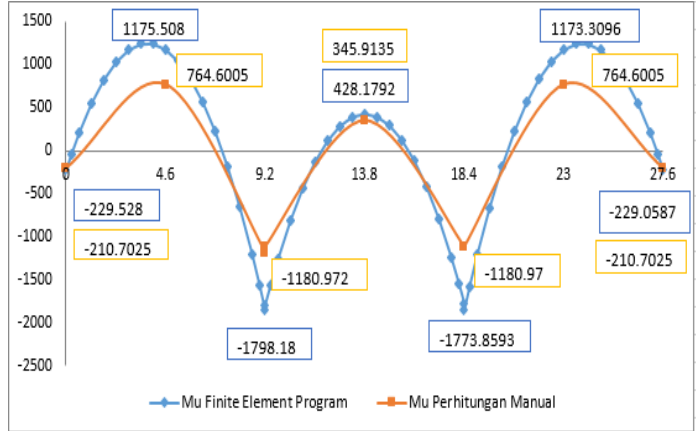

Gambar 4. Diagram momen sistem waffle slab

Dari tabel di atas kemudian diperoleh grafik sebagai berikut untuk melihat hubungan pengaruh tebal pelat terhadap momen lentur tension control pada sistem pelat konvensional dan sistem waffle slab seperti yang ditunjukan pada Gambar 5 dan Gambar 6.

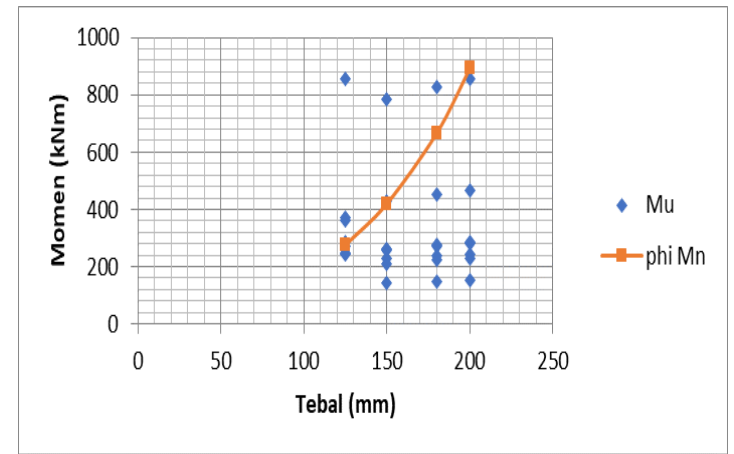

Gambar 5. Hubungan pengaruh tebal pelat terhadap momen lentur tension control pada sistem pelat konvensional

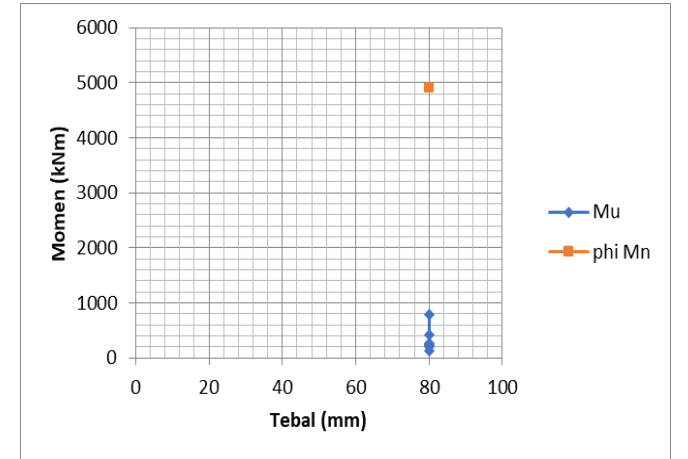

Gambar 6. Hubungan pengaruh tebal pelat terhadap momen lentur tension control pada sistem waffle slab

\section{Rekapitulasi penulangan pelat}

Berdasarkan dari hasil analisis struktur equivalent frame method dan finite element program maka akan diperoleh momen yang kemudian digunakan untuk melakukan analisis penulangan pelat. Hasil rekapitulasi penulangan pada pelat dapat dilihat pada Tabel 5 .

Tabel 5. Rekapitulasi penulangan pelat

\begin{tabular}{|c|c|c|c|c|c|c|c|c|c|}
\hline \multicolumn{5}{|c|}{ PELAT KONVENSIONAL } & \multicolumn{5}{|c|}{ WAFFLE SLAB } \\
\hline Span Lo & ion (Arah & $\begin{array}{c}\text { Momen } \\
\text { (kNm) }\end{array}$ & $\begin{array}{c}\text { Jarak } \\
\text { (mm) }\end{array}$ & Tulangan & Span Lo & ion (Arah & $\begin{array}{l}\text { Momen } \\
(\mathbf{k N m})\end{array}$ & $\begin{array}{l}\text { Jarak } \\
(\mathbf{m m})\end{array}$ & Tulangan \\
\hline \multicolumn{5}{|c|}{ End Span } & \multicolumn{5}{|c|}{ End Span } \\
\hline \multirow[t]{3}{*}{$\begin{array}{l}\text { Column } \\
\text { Strip }\end{array}$} & $\begin{array}{l}\text { Exterior } \\
\text { Negative }\end{array}$ & 243.42 & 143.75 & D13-150 & $\begin{array}{l}\text { Column } \\
\text { Strip }\end{array}$ & $\begin{array}{c}\text { Exterior } \\
\text { Negative }\end{array}$ & 39.3703 & 209.0909 & D13-200 \\
\hline & Positive & 466.699 & 73.0159 & D13-70 & & Positive & 705.3046 & & $\begin{array}{c}\text { 2D25/ribs (6 } \\
\text { ribs) }\end{array}$ \\
\hline & $\begin{array}{l}\text { Interior } \\
\text { Negative }\end{array}$ & 854.016 & 77.9661 & D19-75 & & $\begin{array}{c}\text { Interior } \\
\text { Negative }\end{array}$ & 1177.309 & 148.3871 & D19-145 \\
\hline \multirow[t]{3}{*}{$\begin{array}{l}\text { Middle } \\
\text { Strip }\end{array}$} & $\begin{array}{l}\text { Exterior } \\
\text { Negative }\end{array}$ & 0 & 0 & 0 & $\begin{array}{l}\text { Middle } \\
\text { Strip }\end{array}$ & $\begin{array}{l}\text { Exterior } \\
\text { Negative }\end{array}$ & 0 & 0 & \\
\hline & Positive & 284.672 & 124.324 & D13-120 & & Positive & 392.4364 & & $\begin{array}{c}\text { 2D19/ribs (5 } \\
\text { ribs) }\end{array}$ \\
\hline & $\begin{array}{c}\text { Interior } \\
\text { Negative }\end{array}$ & 279.117 & 124.324 & D13-120 & & $\begin{array}{c}\text { Interior } \\
\text { Negative }\end{array}$ & 390.8466 & 460 & D19-450 \\
\hline \multicolumn{5}{|c|}{ Interior Span } & \multicolumn{5}{|c|}{ Interior Span } \\
\hline $\begin{array}{l}\text { Column } \\
\text { Strip }\end{array}$ & Positive & 228.937 & 153.333 & D13-150 & $\begin{array}{l}\text { Column } \\
\text { Strip }\end{array}$ & Positive & 256.9075 & & $\begin{array}{c}\text { 2D19/ribs (6 } \\
\text { ribs) }\end{array}$ \\
\hline $\begin{array}{l}\text { Middle } \\
\text { Strip }\end{array}$ & Positive & 152.624 & 184 & D13-180 & $\begin{array}{l}\text { Middle } \\
\text { Strip }\end{array}$ & Positive & 171.2717 & & $\begin{array}{l}\text { 2D19/ribs (5 } \\
\text { ribs) }\end{array}$ \\
\hline
\end{tabular}


Tabel 5. Rekapitulasi penulangan pelat (Lanjutan)

\begin{tabular}{|c|c|c|c|c|c|c|c|c|c|}
\hline \multicolumn{2}{|c|}{$\begin{array}{l}\text { Span Location (Arah } \\
\text { Y) }\end{array}$} & \multirow{2}{*}{$\begin{array}{l}\text { Momen } \\
(\mathrm{kNm})\end{array}$} & \multirow[t]{2}{*}{ Jarak } & \multirow[t]{2}{*}{ Tulangan } & \multicolumn{2}{|c|}{$\begin{array}{l}\text { Span Location (Arah } \\
\text { Y) }\end{array}$} & \multirow{2}{*}{$\begin{array}{c}\text { Momen } \\
(\mathrm{kNm})\end{array}$} & \multirow[t]{2}{*}{ Jarak } & \multirow[t]{2}{*}{ Tulangan } \\
\hline & & & & & & & & & \\
\hline \multirow[t]{3}{*}{$\begin{array}{l}\text { Column } \\
\text { Strip }\end{array}$} & $\begin{array}{l}\text { Exterior } \\
\text { Negative }\end{array}$ & 368.072 & 93.8776 & D13-90 & $\begin{array}{l}\text { Column } \\
\text { Strip }\end{array}$ & $\begin{array}{l}\text { Exterior } \\
\text { Negative }\end{array}$ & 203.0665 & 209.0909 & D13-200 \\
\hline & Positive & 422.366 & 80.7018 & D13-80 & & Positive & 604.6069 & & $\begin{array}{l}\text { 2D25/ribs (6 } \\
\text { ribs) }\end{array}$ \\
\hline & $\begin{array}{c}\text { Interior } \\
\text { Negative }\end{array}$ & 978.37 & 82.1429 & D19-80 & & $\begin{array}{c}\text { Interior } \\
\text { Negative }\end{array}$ & 1440.98 & 121.0526 & D19-145 \\
\hline \multirow[t]{4}{*}{$\begin{array}{l}\text { Middle } \\
\text { Strip }\end{array}$} & $\begin{array}{l}\text { Exterior } \\
\text { Negative }\end{array}$ & 0 & 0 & 0 & $\begin{array}{l}\text { Middle } \\
\text { Strip }\end{array}$ & $\begin{array}{l}\text { Exterior } \\
\text { Negative }\end{array}$ & 0 & 0 & \\
\hline & Positive & 281.577 & 124.324 & D13-120 & & Positive & 403.0713 & & $\begin{array}{l}\text { 2D19/ribs (5 } \\
\text { ribs) }\end{array}$ \\
\hline & $\begin{array}{c}\text { Interior } \\
\text { Negative }\end{array}$ & 326.123 & 106.977 & D13-100 & & $\begin{array}{c}\text { Interior } \\
\text { Negative }\end{array}$ & 480.3266 & 383.3333 & D19-300 \\
\hline & \multicolumn{4}{|c|}{ Interior Span } & \multicolumn{5}{|c|}{ Interior Span } \\
\hline $\begin{array}{l}\text { Column } \\
\text { Strip }\end{array}$ & Positive & 412.73 & 83.6364 & D13-80 & $\begin{array}{l}\text { Column } \\
\text { Strip }\end{array}$ & Positive & 602.5102 & & $\begin{array}{c}\text { 2D19/ribs (6 } \\
\text { ribs) }\end{array}$ \\
\hline $\begin{array}{l}\text { Middle } \\
\text { Strip }\end{array}$ & Positive & 275.154 & 184 & D13-180 & $\begin{array}{l}\text { Middle } \\
\text { Strip }\end{array}$ & Positive & 401.6735 & & $\begin{array}{l}\text { 2D19/ribs (5 } \\
\text { ribs) }\end{array}$ \\
\hline
\end{tabular}

\section{Rekapitulasi volume beton dan tulangan baja}

Berdasarkan hasil analisis penulangan pelat, makan dapat diperoleh volume beton, volume tulangan baja dan berat tulangan baja untuk masing-masing sistem pelat. Hasil analisis volume beton, volume tulangan baja, dan berat tulangan baja dapat dilihat pada Tabel 6 .

Hasil analisis untuk jarak antar kolom yang sama yaitu 9,2 m menunjukan bahwa sistem pelat konvensional membutuhkan volume beton beton dan volume tulangan baja yang lebih besar dibandingkan dengan sistem waffle slab. Pada sistem pelat konvensional, volume beton yang dibutuhkan lebih boros $22,178 \%$ dan volume tulangan baja yang dibutuhkan lebih boros $71,976 \%$ dari sistem waffle slab.

Tabel 6. Rekapitulasi volume beton dan tulangan baja

\begin{tabular}{|c|c|c|c|c|c|c|c|}
\hline \multicolumn{4}{|c|}{ Sistem Pelat Konvensional } & \multicolumn{4}{|c|}{ Sistem Waffle Slab } \\
\hline Keterangan & $\begin{array}{c}\text { Volume } \\
\text { Beton }\left(\mathbf{m}^{3}\right)\end{array}$ & $\begin{array}{c}\text { Volume } \\
\text { Tulangan } \\
\text { Baja }\left(\mathbf{m}^{3}\right)\end{array}$ & $\begin{array}{c}\text { Berat } \\
\text { Tulangan } \\
\text { Baja (kg) }\end{array}$ & Keterangan & $\begin{array}{c}\text { Volume } \\
\text { Beton } \\
\left(\mathbf{m}^{3}\right)\end{array}$ & $\begin{array}{c}\text { Volume } \\
\text { Tulangan } \\
\text { Baja }\left(\mathbf{m}^{3}\right)\end{array}$ & $\begin{array}{c}\text { Berat } \\
\text { Tulangan } \\
\text { Baja (kg) }\end{array}$ \\
\hline $\begin{array}{c}\text { Pelat } \\
\text { dengan } \\
\text { Tebal } 200 \\
\text { mm }\end{array}$ & 101.5680 & - & & $\begin{array}{c}\text { Pelat } \\
\text { dengan } \\
\text { Tebal } 80 \\
\text { mm }\end{array}$ & 83.1312 & - & \\
\hline D13 & & 1.4702 & 11541.4549 & D13 & & 0.1343 & 1054.4519 \\
\hline D19 & & 0.7538 & 5917.6927 & D19 & & 0.9286 & 7289.6146 \\
\hline & & & & D25 & & 0.2303 & 1807.9964 \\
\hline TOTAL & 101.5680 & 2.2241 & 17459.1476 & TOTAL & 83.1312 & 1.2933 & 10152.0628 \\
\hline
\end{tabular}




\section{KESIMPULAN DAN SARAN}

\section{Kesimpulan}

Berdasarkan hasil analisis yang telah dilakukan, dapat disimpulkan beberapa hal yaitu:

1. Dengan bentang jarak antar kolom yang sama, lendutan pada sistem pelat konvensional lebih besar dibandingkan dengan sistem waffle slab. Bila di rata-rata, terdapat perbedaan nilai lendutan sekitar $130 \%$.

2. Jarak antar kolom maksimum pada sistem pelat konvensional adalah 9,2 m, sedangkan pada sistem waffle slab adalah 12,5 m, maka jarak antar kolom pada sistem waffle slab lebih panjang $35 \%$ dibandingkan dengan sistem pelat konvensional.

3. Untuk jarak antar kolom yang sama yaitu 9,2 m dan memenuhi syarat dari segi kekakuan dan segi kekuatan, tebal pelat pada sistem pelat konvensional adalah $200 \mathrm{~mm}$ dan tebal pelat pada sistem waffle slab adalah 80 $\mathrm{mm}$, maka sistem waffle slab memiliki tebal pelat lebih tipis $150 \%$ dari sistem pelat konvensional.

4. Untuk jarak antar kolom yang sama, volume beton pada sistem pelat konvensional sebesar $101,568 \mathrm{~m}^{3}$, sedangkan volume beton pada sistem waffle slab sebesar $83,1312 \mathrm{~m}^{3}$, maka volume beton pada sistem pelat konvensional lebih boros 22,178 \% dari sistem waffle slab.

5. Untuk jarak antar kolom yang sama, volume tulangan baja pada sistem pelat konvensional sebesar $2,2241 \mathrm{~m}^{3}$, sedangkan volume tulangan baja pada sistem waffle slab sebesar 1,2933 $\mathrm{m}^{3}$, maka volume tulangan baja pada sistem pelat konvensional lebih boros $71,976 \%$ dari sistem waffle slab.

\section{Saran}

Berdasarkan hasil analisis yang dilakukan, maka saran yang dapat diberikan penulis yaitu:

1. Untuk penelitian selanjutnya, dapat dilakukan analisis dengan adanya pengaruh dari beban gempa yang tidak diperhitungkan dalam studi penelitian ini.

2. Untuk penelitian selanjutnya, dapat dilakukan analisis gedung untuk melihat kajian efisiensi sistem waffle slab terhadap pelat kovensional sehingga lebih akurat.

\section{DAFTAR PUSTAKA}

Idham, N. C. (2012). Merancang Bnagunan Gedung Bertingkat Rendah. Graha Ilmu, Yogyakarta

Nasution, A. (2009). Analisis dan Desain Struktur Beton Bertulang. IYB, Bandung

Park, R. and Gamble, W. L. (1980). Reinforced Concrete Slab. John Wiley and Sons, Canada

Pillai, S. U., and Menon, D. (2003). Reinforced Concrete Design. Tata-McGraw Hill, New Delhi

Puspantoro, B. (1993). Teori dan Analisis Balok Grid. Andi Offset, Yogyakarta

SNI 2847:2013. 2013. Persyaratan Beton Struktural untuk Bangunan Gedung. Badan Standardisasi Nasional. Jakarta.

Structure Point. (2017). “Two-way Joist (Waffle Slab) Concrete Floor System Analysis and Design”. Tersedia di https://www.structure-point.org/publication/pdf/Two-Way-Joist-Concrete-Waffle-Slab-Floor-DesignDetailing_.pdf (26 Agustus 2018)

Susanti, E., Youlanda, N. A., and Winaya, A. (2016). "Studi Perbandingan Pelat Berusuk Dua Arah (Waffle Slab) dan Pelat Konvensional". Jurnal IPTEK, 20(1), 25-36

Wang, C. K., and Salmon, C. G. (1994). Disain Beton Bertulang. Erlangga, Jakarta

Wight, J. K. (2016). Reinforced Concrete Mechanics and Design. Pearson, New Jersey 